\title{
Traumatic carotid-cavernous fistula: excellent demonstration on 3D CT angiography
}

\author{
Ankur Goyal, Sanjay Sharma
}

Department of Radiodiagnosis, All India Institute of Medical Sciences (AllMS), New Delhi, India

\section{Correspondence to}

Dr Sanjay Sharma, drssharma@hotmail.com
To cite: Goyal A, Sharma S. BMJ Case Rep Published online: [please include Day Month Year] doi:10.1136/ bcr-2013-201707

\section{DESCRIPTION}

A 32-year-old man, presented with right proptosis, chemosis and double vision since 2 months. There was a history of head injury following a road traffic accident 3 months ago, but no records were available. On examination, there was pulsatile proptosis, audible bruit and raised intraocular pressure. The patient underwent a dual-phase CT on a 16-slice scanner (Brilliance CT 16, Philips). A non-ionic iodinated contrast $60 \mathrm{~mL}$ (iodine $300 \mathrm{mg} / \mathrm{mL}$ ) was injected through an intravenous cannula at $4 \mathrm{ml} / \mathrm{s}$ using a pressure injector followed by $30 \mathrm{~mL}$ saline flush at the same rate. CT acquisition was triggered using bolus tracking with $4 \mathrm{~s}$ delay for arterial phase and $5 \mathrm{~s}$ interscan delay for venous phase. Scans were obtained with a detector collimation of $16 \times 0.75 \mathrm{~mm}$ at $120 \mathrm{kV}$ and $150 \mathrm{mAs}$. Coronal and sagittal multiplanar reformats, maximal intensity projections and three-dimensional (3D) volume rendering technique (VRT) were used for postprocessing.

In the arterial phase (CT angiogram), there was contrast opacification of the right cavernous sinus (CS), the superior ophthalmic vein (SOV) and

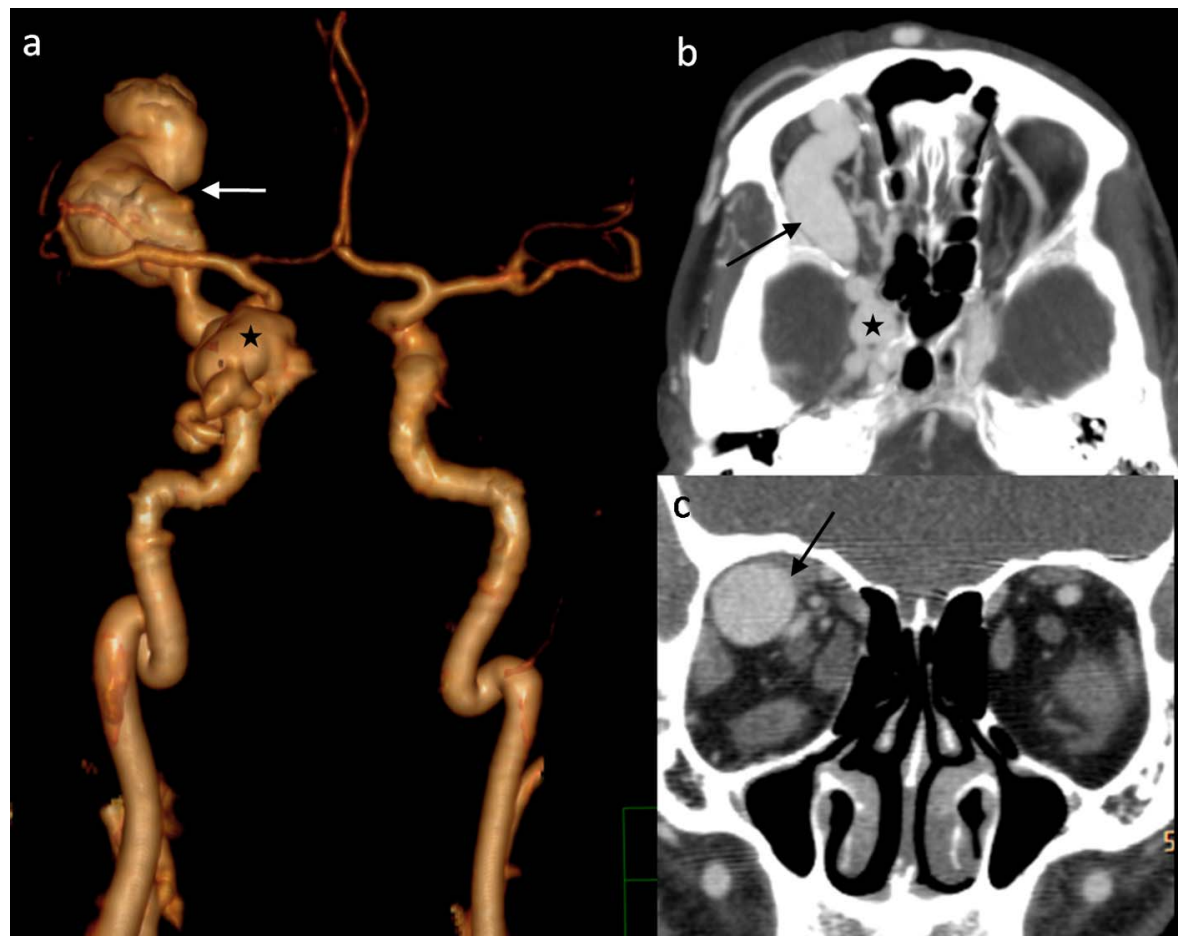

Figure 2 (A) Frontal view of three-dimensional CT angiogram obtained with volume rendering technique (with bone subtracted) demonstrates enlargement of the right cavernous sinus (asterisk) and tortuous dilation of the right superior ophthalmic vein (arrow), in continuation with the right internal carotid artery suggesting carotid-cavernous fistula. (B) Axial maximal intensity projection and (C) coronal multiplanar reformat images showing dilated right superior ophthalmic vein (arrow), bulging right cavernous sinus (asterisk in B) and bulky extraocular muscles on the right side. 
bilateral superficial facial veins (figures 1 and 2). There was direct communication of the right internal carotid artery with the right CS. The latter was bulky and bulging laterally with multiple tortuous channels within. The right SOV was dilated and tortuous. The right extraocular muscles (EOMs) were thickened and enlarged. No craniofacial fracture was seen. However, note was made of a fracture mid-shaft of the right clavicle. Diagnosis of direct right-sided carotid-cavernous fistula (CCF) was made.

CCFs are rare abnormal communications between the cavernous part of the carotid arterial system and the CS. Traumatic CCFs usually are direct high-flow shunts (Barrow type A) affecting young males. Owing to recent technical developments, CT/ MR angiography serve as non-invasive tools for safe diagnosis of vascular lesions like CCF, with similar accuracy as digital subtraction angiography. ${ }^{1}{ }^{2}$ Morphological changes including bulging CS, dilated SOV, bulky EOMs, proptosis and prominent superficial facial veins are well depicted and represent increased venous drainage through the CS, anteriorly into the ophthalmic and facial venous system. Though interpretation of axial source images is an essential part of assessment, postprocessing with 3D softwares provides excellent demonstration for clinical appraisal. VRT generates realistic 3D images, highlighting vessels and bones, and provides accurate depiction of anatomical relationships. ${ }^{1}$

\section{Learning points}

- CT/MR angiography are non-invasive reliable tools for safe diagnosis of vascular lesions like carotid-cavernous fistula.

- Though interpretation of axial source images is an essential part of assessment, three-dimensional (3D) postprocessing softwares provide excellent demonstration for clinical appraisal.

- Volume rendering technique generates realistic 3D images, highlighting vessels and bones, and provides accurate depiction of anatomical relationships.

Contributors Both authors have contributed to the design of the manuscript, data acquisition and interpretation, drafting the article and approving the final version.

Competing interests None.

Patient consent Obtained.

Provenance and peer review Commissioned; internally peer reviewed.

\section{REFERENCES}

1 Coskun O, Hamon M, Catroux G, et al. Carotid-cavernous fistulas: diagnosis with spiral CT angiography. AJNR Am J Neuroradiol 2000;21:712-16.

2 Chen CC, Chang PC, Shy CG, et al. CT angiography and MR angiography in the evaluation of carotid cavernous sinus fistula prior to embolization: a comparison of techniques. AJNR Am J Neuroradiol 2005;26:2349-56.

Copyright 2013 BMJ Publishing Group. All rights reserved. For permission to reuse any of this content visit

http://group.bmj.com/group/rights-licensing/permissions.

BMJ Case Report Fellows may re-use this article for personal use and teaching without any further permission.

Become a Fellow of BMJ Case Reports today and you can:

- Submit as many cases as you like

- Enjoy fast sympathetic peer review and rapid publication of accepted articles

- Access all the published articles

- Re-use any of the published material for personal use and teaching without further permission

For information on Institutional Fellowships contact consortiasales@bmjgroup.com

Visit casereports.bmj.com for more articles like this and to become a Fellow 